\title{
Resistance and resilience of a coral reef fish community to changes in coral cover
}

\author{
Sally J. Holbrook ${ }^{1,2, *}$, Russell J. Schmitt ${ }^{1,2}$, Andrew J. Brooks ${ }^{1}$ \\ ${ }^{1}$ Coastal Research Center, Marine Science Institute, and ${ }^{2}$ Department of Ecology, Evolution and Marine Biology, \\ University of California, Santa Barbara, California 93106-9610, USA
}

\begin{abstract}
Coral reefs are being degraded worldwide by perturbations that range from local disturbances to large-scale climate forcing. To gain insight into possible responses of the fish community to losses of live coral, we surveyed large plots that represented the range in cover of live coral in lagoons of Moorea, French Polynesia, to explore relationships between cover of live coral and 3 attributes of the associated fish community: species richness, total abundance, and species composition. All measured attributes of the fish community were insensitive to changes in live coral cover over a wide range before falling sharply as live coral cover approached zero. A field experiment in which the percentage of living tissue of branching coral was varied while total coral volume and structural complexity were kept constant revealed a rapidly asymptotic relationship of fish richness with increases in cover of live coral that was qualitatively identical to the pattern documented in our surveys. There was qualitative agreement in the pattern of abundance response of fish with variation in cover of live coral between the experiment and field surveys. While the structural heterogeneity provided by coral skeletons can influence the local fish assemblage, the experiment reported here demonstrates that the amount of living coral tissue alone can have a substantial effect on the structure of the fish assemblage. Taken together, the results suggest that local fish assemblages could be resistant to variation in abundance of live coral, changing significantly only as coral becomes rare, while recovery may occur with only modest increases in live coral.
\end{abstract}

KEY WORDS: Resistance - Resilience - Coral reefs - Coral reef fish - Climate change $\cdot$ Diversity Habitat degradation · Species richness · Disturbance

\section{INTRODUCTION}

There is mounting urgency to understand how ecosystems respond to natural and anthropogenic perturbations because of forecasted increases in their frequency, intensity, and/or spatial scale (Vitousek et al. 1997). In addition to understanding how perturbations may alter structural (e.g. biodiversity, species composition) and functional (e.g. productivity) components of natural communities, it is important to gauge ecosystem stability to the disturbance regime. One aspect of stability is resistance, i.e. the amount of disturbance a system can absorb without undergoing a fundamental change (Grimm \& Wissel 1997). A second measure of stability is resilience: the rate of recovery of a system to a former condition following a temporary disturbance (Pimm 1984, Grimm \& Wissel 1997). The capacity of a system to resist state change and recover from perturbations has practical implications that warrant the growing attention on these aspects of natural communities (Syms \& Jones 2000, Miller et al. 2007, Wertz et al. 2007).

Of particular interest are perturbations to foundation species because of the great potential for secondary effects on community structure and function. Organisms such as giant kelp on temperate marine reefs and hermatypic corals on tropical marine reefs are foundation species because of their central role as primary producers in their respective ecosystems and because they serve as a major source of habitat structure. 
Habitat degradation has been identified as a major cause of loss of biodiversity in terrestrial systems (Vitousek et al. 1997), and it is increasingly recognized as an important driver in marine ecosystems (Munday 2004, Wilson et al. 2006), particularly where organisms supply significant habitat structure. Reef-building corals, which provide structural habitat for thousands of other species, are subjected to recurrent pulse disturbances (Connell 1997, Hughes \& Connell 1999, McCulloch et al. 2003, Connell et al. 2004, Wilson et al. 2006) and are increasingly threatened by long-term climate forcing (Kleypas et al. 1999, Nyström et al. 2000, Knowlton 2001, Hughes et al. 2003, Pandolfi et al. 2003, Baker et al. 2004, Bellwood et al. 2004, Graham et al. 2006, Lesser 2007). While declines in abundance of hermatypic corals have already occurred at local to regional scales in some localities, there are predictions of widespread loss of coral due to climate change (Hoegh-Guldberg 1999, Knowlton 2001, Hughes et al. 2003).

It is widely appreciated that coral reefs represent the most diverse ecosystems within the marine environment. For example, despite occupying a miniscule portion of the ocean floor $(\sim 0.2 \%)$, coral reefs support upwards of one-third of all known species of marine fishes (Moberg \& Folke 1999, Lough 2008). Although changes in the coral community can affect associated fish assemblages (Halford et al. 2004, Jones et al. 2004, Munday 2004), the ability to predict such responses is still in its infancy (Wilson et al. 2006). In part, this stems from the diverse types of perturbations that can reduce the cover of live coral, degrade reef structure, and/or alter species composition of the local coral assemblage and the fact that different perturbations often interact with one another. Investigations of responses of fish assemblages to disturbances that affect cover of live coral have revealed a range of results, from no apparent change to reductions or even increases in abundance of particular species of fish (Jones \& Syms 1998, Adams \& Ebersole 2004, Halford et al. 2004, Jones et al. 2004, Munday 2004, Downing et al. 2005, Bellwood et al. 2006, Garpe et al. 2006, Pratchett et al. 2006, Wilson et al. 2006, Munday et al. 2008). By their nature, studies of natural disturbances are opportunistic, and investigators have no control over the history, frequency, intensity, or spatial scale of disturbances on reef habitats.

Experimental studies potentially provide a more rigorous approach to estimating effects on local fish assemblages resulting from local scale changes in coral, but to date, few such manipulations have been conducted (Lewis 1997, 1998, Jones \& Syms 1998, Syms \& Jones 2000, 2001, Feary 2007, Feary et al. $2007 \mathrm{a}, \mathrm{b})$. Not surprisingly, individual species with a high ecological dependence on coral often show the strongest responses to natural or experimentally induced variation in abundance of coral (e.g. Lewis 1997, Jones et al. 2004, Munday 2004, Berumen \& Pratchett 2006, Graham et al. 2006, Pratchett et al. 2006, Wilson et al. 2006). Syms \& Jones (2000) found that the most extreme and persistent change in the fish assemblage occurred when the high structural heterogeneity of living corals was reduced experimentally to low-dimensional dead rubble. However, less severe habitat degradation also can measurably affect fish assemblages. For example, experimental reductions in cover of live coral that left the colony structures intact resulted in significantly lower abundances of new fish recruits, and these were predominantly algae-associated fish species (Feary et al. 2007a).

In the present study, we used a combination of surveys and field experimentation in lagoons of Moorea, French Polynesia, to (1) estimate the functional form of the local relationship between variation in coral cover and attributes of the associated fish assemblage, and (2) isolate the influence of variation in cover of living coral tissue from that due to the physical structure of the coral. Surveys yielded information on how species richness, abundance, and taxonomic similarity of the fish assemblage varied across the natural range in cover of live and total (i.e. live + dead) coral. The experiment, conducted using constructed patch reefs, enabled us to verify the larger-scale survey patterns and to explore responses of fish to variation in cover of living coral tissue alone. The estimated functions allowed us to assess resistance of the fish assemblage to changes in their coral habitat and to identify possible tipping points in the system.

\section{METHODS}

Study area. Field work was conducted in lagoons on the north shore of Moorea, French Polynesia $\left(17^{\circ} 30^{\prime} \mathrm{S}\right.$, $\left.149^{\circ} 50^{\prime} \mathrm{W}\right)$, during 2002 to 2003 . The lagoons are 0.8 to $1.3 \mathrm{~km}$ wide, have a mean depth of $\sim 5$ to $7 \mathrm{~m}$, and have a bottom consisting of patch reefs, coral rubble, and sand. More than 600 marine fish species have been reported from the Society Islands in French Polynesia (Randall 1985, 2005), and 280 species were recorded along a single $\sim 1.5 \mathrm{~km}$ transect that extended from shore to the fore-reef on the north side of Moorea (Galzin 1987). We have recorded a cumulative total of $\sim 150$ species on a set of mid-lagoon patch reefs of the coral Porites rus (range in size: $\sim 0.5$ to $2 \mathrm{~m}^{3}$ ) with a maximum of $\sim 30$ species found on any single patch reef (Holbrook et al. 2002a,b, Brooks et al. 2007). In total, 134 fish species were observed in the surveys conducted for the present study. 
Spatial surveys. The number of individual fish by species was quantified in $19500 \mathrm{~m}^{2}(50 \times 10 \mathrm{~m})$ plots all located approximately mid-way between the shore and barrier reef in the Vaipahu and Maharepa lagoons. Plots were chosen to represent the range in cover of live coral present in mid-lagoon habitats (1 to $50 \%$ ), and all were situated in a $7 \mathrm{~km}$ stretch of the north shore of the island. Adjacent plots were no closer than $200 \mathrm{~m}$, and there was no systematic relationship between similarity in cover of live coral and proximity of sites to one another. Scuba divers identified and counted all reef-associated fish and mapped the corals on each survey plot over a 3 mo period during the austral winter. All fish counts were done by the same 2 observers. The total number of species observed by both divers was summed to obtain the species list for a plot. For abundance, we used the larger number observed by the 2 divers for any given species with up to 25 individuals, after which the average of the 2 counts was taken. The divers spent the same amount of time per unit of coral on each plot. Substrates were not disturbed in order to count cryptic fish species, so our estimates of species richness are likely conservative. For each plot, all corals with a diameter $>15 \mathrm{~cm}$ were identified, measured, and mapped (mean $=99$ corals per plot, range 6 to 301), and the percentage of each colony that was alive was estimated. The proportion of the substrate that was occupied by living and by dead coral was calculated for each plot.

Metrics. For each survey plot, species richness was the total number of species of fish observed and total abundance was the sum of the counts for all species. Similarity in species composition was estimated by comparing each survey plot to the plot with the highest cover of live coral using ordination analysis (PC Ord Version 4.27; Sorensen [Bray-Curtis] distance measure used). Taxonomic similarity values were analyzed both on matrices of presence-absence data for species (to compare species lists), as well as on matrices of logtransformed abundance (to compare relative abundance).

Estimating the functional relationships. To statistically assess the shape of the relationships of species richness, total abundance of fish and similarity in species composition with variation in the cover of living coral, fits of the data with the following 3 parameter model (Shepherd 1982, Schmitt et al. 1999) were made:

$$
A=a S /\left[1+(a / b) S^{d}\right]
$$

where $A$ is the dependent variable (species richness, abundance, or similarity) at coral cover $S$, and $a, b$, and $d$ are fitted parameters. $d$ controls the shape of the curve; the relationship is linear when $d=0$, decelerating but not saturating when $0<d<1$, saturating when $d=1$, and dome-shaped when $d>1$ (Shepherd 1982).
For each comparison, we estimated the value and 95\% confidence interval for $d$ using SAS Proc NLIN (v. 9.1). When $d=1$, a represents the initial slope of the relationship, $b$ the asymptotic value, and $b / a$ the half-saturation point (the point at which the response variable reaches $50 \%$ of its asymptotic value). The advantage of using this statistical approach is that the shape of the relationships can be tested directly through the values of the parameter $d$.

Experimental test of effect of live coral cover. In the surveys, the cover of live coral co-varied positively with the cover of dead coral among plots. To help establish causation for patterns observed in the surveys and to isolate the effect of variation in living coral tissue from variation in habitat complexity, we conducted an experiment where the total volume and structural heterogeneity of coral were held constant among plots while the proportion of live coral was manipulated to mirror the range in cover of living coral observed in the surveys. We constructed 25 experimental patch reefs (hereafter 'experimental plots') each $1 \mathrm{~m}^{2}$ in area on a sand plain in the Maharepa lagoon by transplanting live and dead colonies of the branching coral Pocillopora eydouxi using established techniques (Schmitt \& Holbrook 2000). This experiment was not intended to replicate natural multispecies sets of corals; rather, it tested responses of the fish assemblage to differences in the proportion of live versus dead cover of one of the most common branching corals observed in the lagoons of Moorea when total volume and structural complexity were held constant. Adjacent experimental plots were $>15 \mathrm{~m}$ apart. Colonies of $P$. eydouxi, 4 to 6 per plot, were placed on a plot such that each contained an equal volume and physical structure of coral. Treatment levels were the percent of the coral colonies that was alive $(0,25,50$, 75 , or $100 \%$ ), which corresponded to a treatment mean of $0,9,24,42$, or $48 \%$ of the bottom of the plot being covered by living coral. There were 5 replicate plots within each level of the live cover treatment, and individual treatment levels were assigned to experimental plots using a complete block design.

Survival of transplanted live corals was $100 \%$, and deterioration of the dead corals was minimal, so total volume of coral (both live and dead) as well as structural complexity of all experimental plots remained similar and unvarying throughout the experiment. Dead corals did not accumulate macroalgae. At the start of the experiment, no fish were present on the plots, but fish rapidly colonized via recruitment of larval stages and immigration of older individuals. Counts of all fish associated with each plot were made by scuba divers every 3 mo; for each sampling period, duplicate fish counts were made on 2 different days. Here we report counts on experimental plots made at 12 mo to avoid initial 
transient behavior and to match the seasonal period (austral winter) when the large plots were surveyed.

One-way analysis of variance (ANOVA) was used to test for differences in species richness among the live coral cover treatments. In addition, we used the 3 parameter Shepherd model described above to statistically determine the shape of the functional relationship between species richness and cover of live coral in the experiment. To minimize effects of demographic stochasticity due to the small size of an experimental plot, we used the cumulative number of species observed on all 5 experimental plots within a treatment level to assess the relationship of species richness with cover of live coral tissue.

To assess whether the structure of the assemblage that formed on the experimental plots was similar to that on natural reef areas, we categorized species into 6 general trophic groups based on information reported in the literature (e.g. Randall 2005): herbivores, meso- (and micro-) carnivores, corallivores, piscivores, planktivores, and omnivores. We operationally defined omnivores as species that consumed organisms on 3 or more trophic levels (e.g. algae, crustaceans, coral polyps, fishes). Many of the piscivores also ate smaller invertebrates, but meso-carnivores never consumed fishes. Similarly, corallivores only or primarily derived nutrition from coral tissue. We calculated the proportion that each trophic group represented of the total number of species in each plot type (i.e. of 134 species from natural plots; 34 species from experimental plots). Trophic groups were ordered with respect to numerical dominance in each plot type, and the Spearman rank correlation coefficient (with tied observations receiving the same ranks) was calculated to assess the match in rankings.

We also gauged how specific taxa in the assemblage on the experimental plots responded to variation in live coral cover, based on knowledge of habitat requirements and data from the spatial surveys. First, we identified species $(\mathrm{N}=5)$ in the assemblage that are known to occur only in live branching coral, and we examined whether they occurred in experimental plots that contained only the dead branching coral skeletons. Second, we assessed abundance patterns across the range of coral cover in the experiment for all species where at least 10 individuals were enumerated ( $\mathrm{N}=8$ species). This was done by comparing total abundance of each species on the 2 treatments with lowest coral cover to abundance on the 2 highest coral cover treatments. Earlier we had used a similar approach with the 'core' assemblage of 29 species from 13 different families seen in the survey plots (Holbrook et al. 2006). In that analysis, species exhibited 3 different patterns of variation in abundance among the sites. As cover of live coral increased across the sites, 16 species increased in abundance, 5 species decreased, and 8 species did not change (Holbrook et al. 2006). The patterns of abundance exhibited by the 8 species in the experiment were compared to their pattern already reported by Holbrook et al. (2006) for the spatial surveys.

\section{RESULTS}

We observed a total of 9879 fish of 134 species in 30 families in the survey of the $500 \mathrm{~m}^{2}$ natural plots. Most species in the assemblage were represented by few individuals, with $84 \%$ of the 134 species each constituting $<1 \%$ of the total number of individuals sampled. Both species richness and total abundance of fish (Fig. 1) showed rapidly decelerating relationships with increases in cover of live coral. The relationships were characterized by steep initial increases over the lowest values of coral cover, with relatively little to no change after live cover exceeded $\sim 10 \%$. Statistical analyses indicated that the relationship was asymptotic for species richness $\left(d=0.97 \pm 0.16\right.$; mean $\pm 95 \% \mathrm{CI}_{\text {; }}$ see 'Methods') and nearly so for abundance $(d=0.83 \pm 0.16$; mean $\pm 95 \%$ CI). The estimated half-saturation point for species richness occurred when cover of living coral was just $1.1 \%$. Thus, richness of the fish assemblage was relatively insensitive to variation in cover of live coral over virtually all of the range in cover, but was reduced precipitously when live coral was rare. This did not stem from limitations imposed by the local species pool, because even the most speciose plots contained less than half of all species enumerated during our surveys, and an even smaller fraction of the species known to occur on the north shore of Moorea (Galzin 1987, Holbrook et al. 2002a,b, Brooks et al. 2007). The pattern for total abundance of fish was slightly different in that fish gradually declined in abundance over most of the range in coral cover; however, the sharp decline in fish abundance over the lowest values for coral cover was similar to the pattern for species richness (Fig. 1).

Our estimate of species composition (i.e. taxonomic similarity of each plot to that having the highest cover of live coral) was also a rapidly saturating function of live coral cover $(d=0.96 \pm 0.16$; mean $\pm 95 \% \mathrm{CI})$. Hence, species composition remained similar across a broad range of live coral cover until taxonomic similarity declined sharply when live coral cover fell below $\sim 10 \%$ (Fig. 1). Results were robust regardless of whether taxonomic similarity was calculated based on presence-absence data or when relative abundance data were incorporated in calculating similarity $(d=$ $0.88 \pm 0.18$; mean $\pm 95 \% \mathrm{CI}$ ). Thus, like species richness and total abundance, species composition of the assemblage was quite resistant to variation in cover of live coral except when it was rare. 

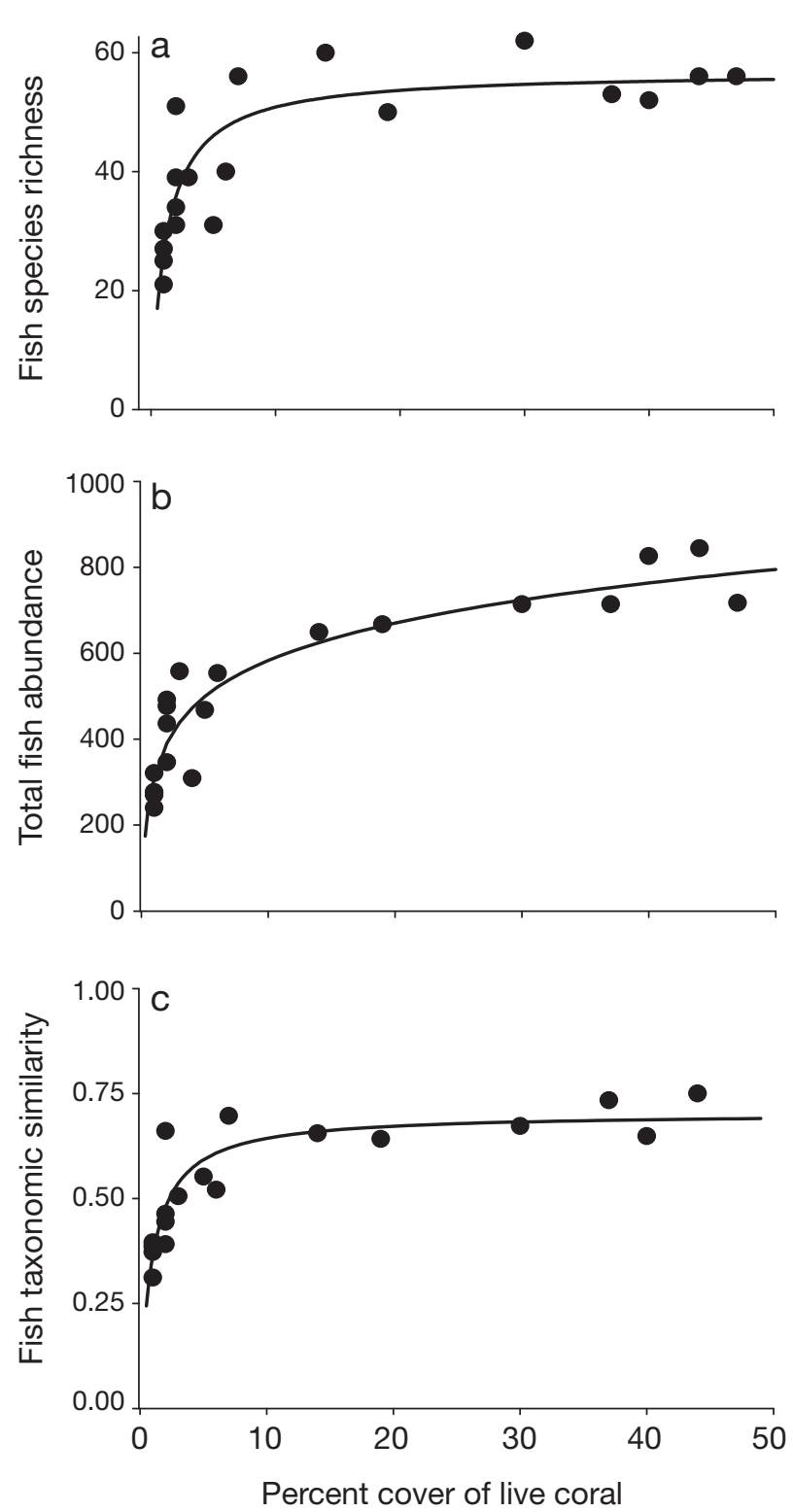

Fig. 1. (a) Species richness (number of species per plot), (b) total abundance (number of individuals per plot), and (c) taxonomic similarity of reef-associated fishes surveyed in $500 \mathrm{~m}^{2}$ lagoon plots over the natural range in cover of live coral in lagoons of Moorea, French Polynesia. Lines are fits to the Shepherd (1982) function

In our spatial surveys, the cover of live coral covaried positively among plots with that of dead coral $(\mathrm{r}=0.92 ; \mathrm{p}<0.001)$; this means that heterogeneity in physical structure also varied among the plots as a function of total coral cover (live + dead). The field experiment, designed to isolate the role of living coral tissue from other confounding influences, helped us determine whether the observed rapidly saturating relationship for species richness in the survey resulted from responses of the fish assemblage to the amount of live coral, dead coral, or total coral on a plot. Thirtyfour species of fish occurred on the experimental plots after $1 \mathrm{yr}$, and there were significant differences in species richness among the live coral treatments (AVOVA $F_{4,20}=8.82, \mathrm{p}<0.0003$ ). Importantly, the fit of the Shepherd function revealed that the relationship for the experimental plots between species richness and variation in cover of living coral tissue was asymptotic (Fig. $2 ; d=0.93 \pm 0.77$; mean $\pm 95 \%$ CI). The estimated half-saturation point for richness occurred at $1.4 \%$ cover of living coral, a value that is similar to the half-saturation point for species richness observed during the large plot surveys. Thus, despite differences between the experiment and survey with respect to plot size $\left(5\right.$ versus $\left.500 \mathrm{~m}^{2}\right)$, composition of the coral

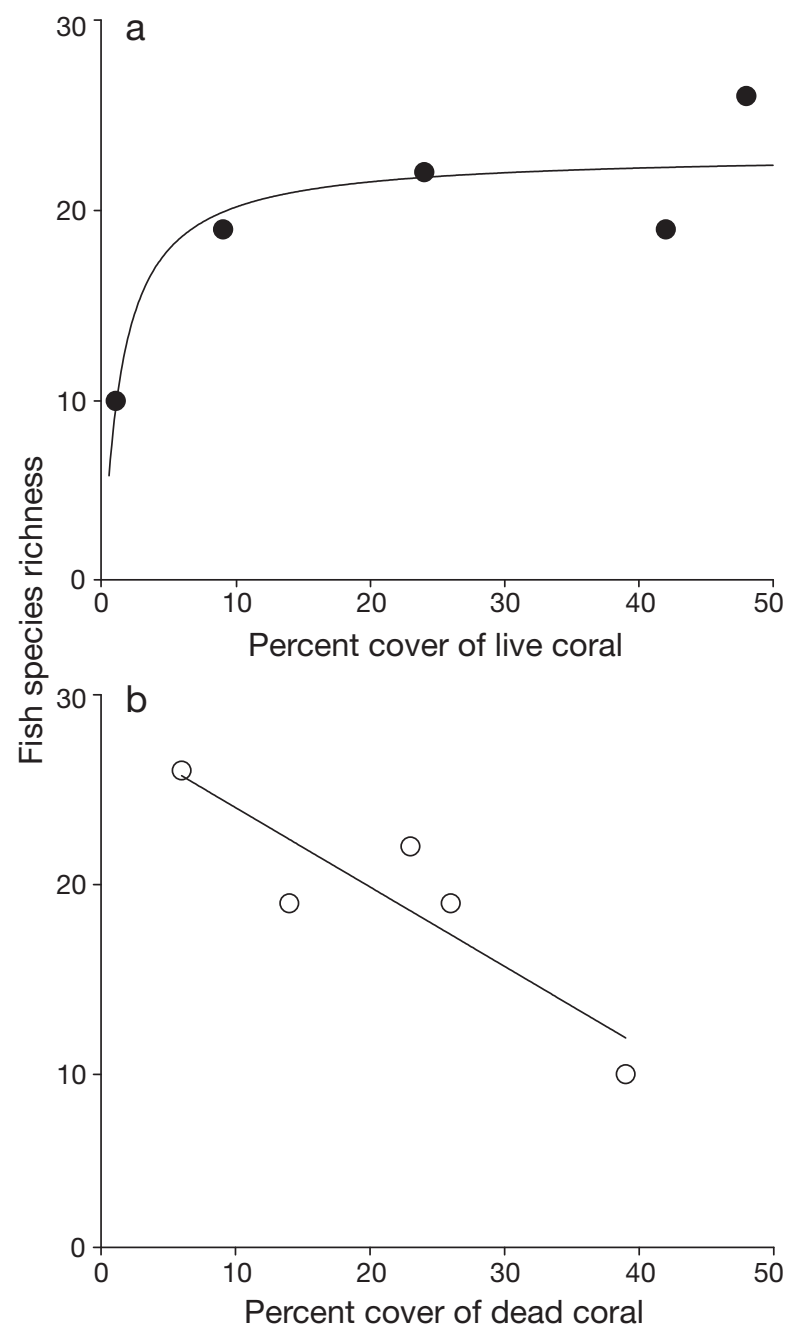

Fig. 2. Relationship between species richness and cover of (a) live coral and (b) dead coral in experimental plots after $1 \mathrm{yr}$; total coral volume was kept constant among the treatments, but the proportion alive was varied. Data represent the cumulative number of species observed across all plots within a live coral cover treatment. Lines represent a fit to the Shepherd (1982) function (a) and linear regression (b) 
assemblage, and number of fish species observed (34 versus 134 species), the relationships between richness and variation in live coral were both qualitatively and quantitatively similar. By contrast, richness declined monotonically with increasing cover of dead coral among experimental treatments (Fig. 2, $\mathrm{r}^{2}=0.95, \mathrm{p}<$ 0.005). Thus, the experiment revealed that species richness is a rapidly saturating function of the cover of live and not dead coral.

The 34 species observed on the experimental plots after 1 yr collectively represented 12 families; the lowest live coral cover treatment had about half as many species and families as did any of the other treatment levels (Table 1). The trophic structure of the fish assemblage that formed on the experimental plots was qualitatively similar to that observed in our survey of natural plots (Fig. 3). Compared to natural plots, species of herbivorous and planktivorous fishes were somewhat over-represented (with a commensurate under-representation of other trophic groups) in the experimental plots (Fig. 3). Nonetheless, Spearman rank correlation indicated that the order of proportional representation of trophic groups was highly correlated between the natural and experimental plots $\left(\mathrm{r}_{\mathrm{s}}=0.89 ; \mathrm{p}<0.05\right)$. Thus, despite differences in plot sizes and variation in morphology of corals present, the trophic structure of the fish assemblage on experimental plots was quite similar to that on natural reef areas.

The responses of species to variation in live coral cover in the experiment were congruent to expectations based on habitat affinities and the patterns of variation observed in the spatial surveys. Of the 5 species known to inhabit live branching coral (Chromis

Table 1. Number of species and of families observed in the 5 treatments of the experiment testing effects of live coral cover on fish species richness. Counts were made 12 mo after initiation of the experiment. The total number of different species observed follows each family name in parentheses

\begin{tabular}{|lccccc|}
\hline & \multicolumn{5}{c}{ Cover of live coral (\%) } \\
& 0 & 9 & 24 & 42 & 48 \\
\hline Acanthuridae (7) & 1 & 1 & 4 & 2 & 5 \\
Balistidae (1) & 0 & 0 & 0 & 1 & 0 \\
Caracanthidae (1) & 0 & 1 & 1 & 1 & 1 \\
Chaetodontidae (1) & 0 & 1 & 1 & 1 & 1 \\
Cirrhitidae (2) & 0 & 1 & 1 & 2 & 2 \\
Gobiidae (2) & 2 & 2 & 2 & 1 & 1 \\
Labridae (8) & 2 & 5 & 3 & 4 & 5 \\
Mullidae (1) & 0 & 1 & 1 & 0 & 0 \\
Pinguipedidae (1) & 1 & 0 & 1 & 0 & 1 \\
Pomacentridae (6) & 2 & 4 & 5 & 5 & 6 \\
Scaridae (2) & 2 & 2 & 1 & 1 & 1 \\
Serranidae (2) & 0 & 1 & 1 & 1 & 3 \\
Total species (34) & 10 & 19 & 21 & 19 & 26 \\
Total families (12) & 6 & 10 & 11 & 10 & 10 \\
\hline
\end{tabular}

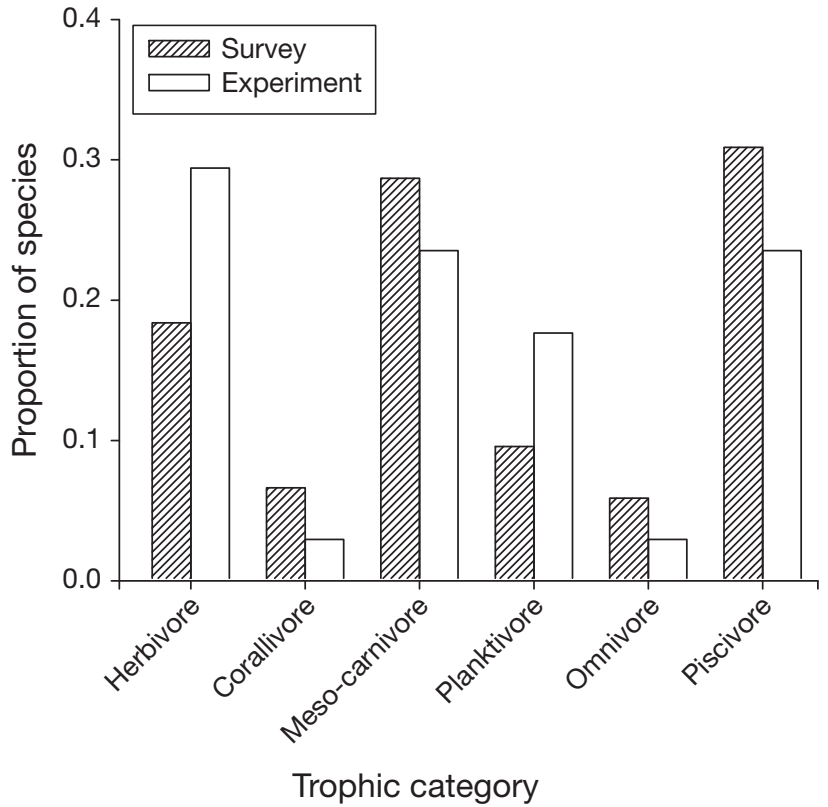

Fig. 3. Trophic composition of the fish community in natural survey plots and after $1 \mathrm{yr}$ in experimental plots. Data are the proportion of species in each general trophic category (survey: $\mathrm{N}=134$ species; experiment: $\mathrm{N}=34$ )

viridis, Dascyllus aruanus, D. flavicaudus, Caracanthus maculatus, Neocirrhites armatus), none was present on experimental plots that contained only dead branching coral. Abundances of 8 additional species across the range of coral cover were examined; 5 species increased in abundance with increases in coral cover (Stegastes nigricans, Chaetodon citrinellus, Paracirrhites arcatus, Pseudocheilinus hexataenia, Thalassoma hardwicke), 2 species declined (Gnatholepis anjerensis, Pomacentrus pavo), and 1 species did not vary (Halichores trimaculatus). These patterns were identical to those quantified for those species in the surveys and reported earlier (Holbrook et al. 2006).

\section{DISCUSSION}

Because ecosystems are subjected to a range of natural and anthropogenic perturbations, ecologists have long sought to understand how community structure, ecosystem processes, and ecosystem properties such as resistance and resilience are likely to respond. Disturbances that alter the abundance of foundation species are of particular interest because of the role foundation species play in providing structural habitat and additional resources for numerous other species. In general, however, we lack sophisticated understanding of the scope of possible effects (e.g. Lawton et al. 1998, Jones et al. 2004). 
Hermatypic corals are the key foundation group of the coral reef ecosystem, and there is a substantial body of work on the effects of disturbances on the local abundance and diversity of corals, as well as on patterns and processes of coral recovery (Connell 1997, Hughes \& Connell 1999, Hughes et al. 2003, Connell et al. 2004, Halford et al. 2004, Grottoli et al. 2006). Corals experience a variety of natural and anthropogenic perturbations that span broad spatial and temporal scales, ranging from acute localized disturbances (e.g. intense storms, outbreaks of predators) to more gradual widespread change in environmental conditions (e.g. climate change). Declines in coral are predicted to increase considerably in the coming decades (Hughes et al. 2003, Pandolfi et al. 2003, Bellwood et al. 2004). As coral reef ecosystems contain about one-third of all known species of marine fish species (Moberg \& Folke 1999), it is critical to understand how changes in the coral community will affect the associated assemblage of fishes.

Our substitution of coral variation in space as a proxy for change over time produced non-obvious insights regarding possible responses of coral reef fish communities to disturbance- and climate-driven reductions in the abundance of live coral. Foremost among these is the possibility that the fish community as a whole may be resistant to declines in living coral over a wide range in coral cover prior to rapid collapse as coral becomes scarce. We found that species richness and the general composition of the fish assemblage remained essentially unchanged across a broad gradient in cover of live coral, and that the total abundance of fish declined only gradually over this same large range. The apparent tipping point for these attributes of the fish community occurred when cover of live coral fell below $5 \%$. The fact that the observed rapidly saturating functions were due to variation in cover of live coral, rather than variation in cover of dead or total coral, was confirmed by our field experiment. The communities that formed on the experimental patches were similar in trophic structure to those on nearby natural reefs, and individual species displayed the same responses to variation in the amount of live coral both in the survey plots and in the experiment. In addition, the relationship between species richness and amount of live coral cover in the experiment had the same asymptotic functional form as that observed in the spatial surveys. While local structural heterogeneity of the habitat is a known influence on the associated fish assemblage, the experiment reported here revealed the important influence of variation in the amount of living coral tissue alone.

Our finding of resistance in the fish community at Moorea, French Polynesia, may explain why, for example, a $90 \%$ decline in cover (from 66 to $7 \%$ ) of branching corals at Kimbe Bay, Papua New Guinea, over an
8 yr period was accompanied by just a $\sim 22 \%$ decline in species richness of the associated fishes (Jones et al. 2004). Similarly, Downing et al. (2005) found little change in species diversity and composition during the 5 yr period following a coral bleaching event that resulted in substantial mortality of coral in portions of their study area (Aldabra Atoll, Seychelles). Indeed, the analysis of published data by Wilson et al. (2006) revealed consistently lower proportionate reductions in fish species richness relative to the magnitude of decline in cover of live coral. If it is the case that the fish assemblage is resistant, tracking attributes of the fish community would not provide an accurate depiction of the overall state of a coral reef ecosystem. Lack of a cohesive response among different taxonomic groups would require that each be tracked to determine the impact of disturbances or climate forcing on attributes of the reef ecosystem. A similar conclusion was drawn for predicting the effects of disturbance on biodiversity in a tropical forest ecosystem (Lawton et al. 1998), underscoring the need for more information to accurately predict effects of disturbances and climate forcing on biodiversity.

Jones et al. (2004) estimated the percent of obligate coral specialists to be about $11 \%$ for Indo-Pacific fish species, and it is reasonable to expect these species to be most severely affected by losses of live coral. A variety of studies have revealed clear patterns of response of these specialized species to variation in abundance of live coral. For example, local populations of 6 species of coral goby in Kimbe Bay, Papua New Guinea, all decreased following a decline in the local abundance of Acropora coral, and the proportional loss increased with the degree to which a goby species specialized on Acropora (Munday 2004). Similarly, responses of butterflyfishes to a decline in coral cover following a bleaching event varied as a function of their dependence on hard corals for food (Pratchett et al. 2006). Consistent with these findings, in the present study, species with known dependence on live branching corals did not colonize the experimental plots that contained only dead Pocillipora.

However, in addition to providing critical resources for specialist species, corals are used by at least 1 life stage of many fishes for a wide variety of functions including feeding, nesting, and sheltering from predators. Because of the variety of lifestyles exhibited by coral reef fishes, and the relatively small proportion completely dependent on live coral, it is not clear how assemblage characteristics such as total abundance or species richness would vary as abundance or diversity of live coral changes. In a meta-analysis involving 12 different studies across a broad geographic range, the amount of loss in species richness of local fish assemblages was related to the severity of temporal decline in 
cover of live coral, although declines in species richness of greater than $20 \%$ occurred only when losses of coral cover were large ( $>50 \%$; Wilson et al. 2006). Also, species richness was sometimes higher following declines in coral, and responses became much more variable as the magnitude of decline in coral increased, with increases at some sites and losses of species richness at others even when cover declined $>50 \%$ (Wilson et al. 2006). The results from our spatial surveys on Moorea suggest possible temporal responses in fish species richness to declines in coral cover. Similar to the findings from the temporal studies reported by Wilson et al. (2006), sites at Moorea with less coral cover sometimes had higher species richness of reef-associated fish than locations with the highest observed cover. Differences in species richness of $>20 \%$ in our spatial dataset occurred only at sites that had $80 \%$ less than the observed maximum cover of live coral.

Studies of the coral and fish assemblages following a severe disturbance on the southern Great Barrier Reef when coral cover declined from $>80$ to $<10 \%$ and most species of fish declined in abundance suggested largescale resilience and predictable recovery (Halford et al. 2004). Recovery of coral was initially slow, but then accelerated and reached pre-impact levels within about a decade. The temporal patterns of fish species richness and abundance largely tracked that of the hard coral (Halford et al. 2004). By contrast, the observed functional relationships in our study suggest that biodiversity, trophic structure, and overall abundance of fishes could essentially recover to their predisturbance states after only a modest return in the cover of living coral. While it might take a long time for the coral community to completely recover (Connell 1997, Hughes \& Connell 1999, Hughes et al. 2003, Connell et al. 2004), the fish assemblage could recover at a much faster rate. There is, of course, an important scale dependency here: the degree of population connectivity needed to buffer local populations against persistent declines in abundance must increase as the spatial scale of disturbance increases (Munday 2004, Steele \& Forrester 2005). Hence, it is unclear whether the fish community is likely to retain relatively great resistance and resilience as the abundance of coral declines on an ever increasing spatial scale as may occur from climate-driven environmental forcing. Nonetheless, these findings suggest that delineating functional relationships between biogenic habitat and associated biota can provide useful insight into likely community-level responses to disturbances on foundation species.

Acknowledgements. We thank K. Seydel for outstanding assistance in the field, and N. Davies, C. Kane, J. Lape, M. Schmitt, T. You-Sing, and J. You-Sing for additional logistical help. We gratefully acknowledge the support of the National Science Foundation (OCE 99-10677; OCE 04-17412), the W. M. Keck Foundation, and the Gordon and Betty Moore Foundation. This is a contribution of the Moorea Coral Reef (MCR) LTER Site and is Contribution No. 91 of the UC Berkeley Gump Research Station.

\section{LITERATURE CITED}

Adams AJ, Ebersole JP (2004) Resistance of coral reef fishes in back reef and lagoon habitats to a hurricane. Bull Mar Sci 75:101-113

> Baker AC, Starger CJ, McClanahan TR, Glynn PW (2004) Corals' adaptive response to climate change. Nature 430:741

Bellwood DR, Hughes TP, Folke C, Nyström M (2004) Confronting the coral reef crisis. Nature 429:827-833

Bellwood DR, Hoey AS, Ackerman JL, Depczynski M (2006) Coral bleaching, reef fish community phase shifts and the resilience of coral reefs. Glob Change Biol 12:1587-1594

> Berumen ML, Pratchett MS (2006) Recovery without resilience: persistent disturbance and long-term shifts in the structure of fish and coral communities at Tiahura Reef, Moorea. Coral Reefs 25:647-653

Brooks AJ, Holbrook SJ, Schmitt RJ (2007) Patterns of microhabitat use by fishes in the patch-forming coral Porites rus. Raffles Bull Zool S14:227-236

> Connell JH (1997) Disturbance and recovery of coral assemblages. Coral Reefs 16:S101-S113

Connell JH, Hughes TP, Wallace CC, Tanner JE, Harms KE, Kerr A (2004) A long-term study of competition and diversity of corals. Ecol Monogr 74:179-210

> Downing N, Buckley R, Stobart B, LeClair L, Teleki K (2005) Reef fish diversity at Aldabra Atoll, Seychelles, during the five years following the 1998 coral bleaching event. Phil Trans R Soc Lond A 363:257-261

> Feary DA (2007) The influence of resource specialization on the response of reef fish to coral disturbance. Mar Biol 153:153-161

> Feary DA, Almany GR, McCormick MI, Jones GP (2007a) Habitat choice, recruitment and the response of coral reef fishes to coral degradation. Oecologia 153:727-737

Feary DA, Almany GR, Jones GP, McCormick MI (2007b) Coral degradation and the structure of tropical reef fish communities. Mar Ecol Prog Ser 333:243-248

Galzin R (1987) Structure of fish communities of French Polynesian coral reefs. II. Temporal scales. Mar Ecol Prog Ser 41:137-145

Garpe KC, Yahya SAS, Lindahl U, Öhman MC (2006) Longterm effects of the 1998 coral bleaching event on reef fish assemblages. Mar Ecol Prog Ser 315:237-247

Graham NAJ, Wilson SK, Jennings S, Polunin NVC, Bijoux JP, Robinson J (2006) Dynamic fragility of oceanic coral reef ecosystems. Proc Natl Acad Sci USA 103:8425-8429

Grimm V, Wissel C (1997) Babel, or the ecological stability discussions: an inventory and analysis of terminology and a guide for avoiding confusion. Oecologia 109:323-344

> Grottoli AG, Rodrigues LJ, Palardy JE (2006) Heterotrophic plasticity and resilience in bleached corals. Nature 440: 1186-1189

> Halford A, Cheal AJ, Ryan D, Williams DMcB (2004) Resilience to large-scale disturbance in coral and fish assemblages on the Great Barrier Reef. Ecology 85:1892-1905

Hoegh-Guldberg O (1999) Climate change, coral bleaching and the future of the world's coral reefs. Mar Freshw Res 50:839-866 
Holbrook SJ, Brooks AJ, Schmitt RJ (2002a) Predictability of fish assemblages on coral patch reefs. Mar Freshw Res 53:181-188

Holbrook SJ, Brooks AJ, Schmitt RJ (2002b) Variation in structural attributes of patch-forming corals and in patterns of abundance of associated fishes. Mar Freshw Res 53:1045-1053

Holbrook SJ, Brooks AJ, Schmitt RJ (2006) Relationships between live coral cover and reef fishes: implications for predicting effects of environmental disturbances. Proc 10th Int Coral Reef Symp: 241-249

Hughes TP, Connell JH (1999) Multiple stressors on coral reefs: a long-term perspective. Limnol Oceanogr 44: 932-940

Hughes TP, Baird AH, Bellwood DR, Card M and others (2003) Climate change, human impacts, and the resilience of coral reefs. Science 301:929-933

Jones GP, Syms C (1998) Disturbance, habitat structure and the ecology of fishes on coral reefs. Aust J Ecol 23:287-298

> Jones GP, McCormick MI, Srinivasan M, Eagle JV (2004) Coral decline threatens fish biodiversity in marine reserves. Proc Natl Acad Sci USA 101:8251-8253

Kleypas JA, Buddemeier RW, Archer D, Gattuso JP, Langdon C, Opdyke BN (1999) Geochemical consequences of increased atmospheric carbon dioxide on coral reefs. Science 284:118-120

Knowlton N (2001) The future of coral reefs. Proc Natl Acad Sci USA 98:5419-5425

Lawton JH, Bignell DE, Bolton B, Bloemers GF and others (1998) Biodiversity inventories, indicator taxa and effects of habitat modification in tropical forest. Nature 391:72-76

Lesser MP (2007) Coral reef bleaching and global climate change: can corals survive the next century? Proc Natl Acad Sci USA 104:5259-5260

Lewis AR (1997) Effects of experimental coral disturbance on the structure of fish communities on large patch reefs. Mar Ecol Prog Ser 161:37-50

Lewis AR (1998) Effects of experimental coral disturbance on the population dynamics of fishes on large patch reefs. J Exp Mar Biol Ecol 230:91-110

Lough JM (2008) 10th anniversary review: a changing climate for coral reefs. J Environ Monit 10:21-29

McCulloch M, Fallon S, Wyndham T, Hendry E, Lough J, Barnes D (2003) Coral record of increased sediment flux to the inner Great Barrier Reef since European settlement. Nature 421:727-731

Miller SW, Wooster D, Li J (2007) Resistance and resilience of macroinvertebrates to irrigation water withdrawals. Freshw Biol 52:2494-2510

Moberg F, Folke C (1999) Ecological goods and services of coral reef ecosystems. Ecol Econ 29:215-233

Editorial responsibility: Charles Peterson,

Morehead City, North Carolina, USA
Munday PL (2004) Habitat loss, resource specialization, and extinction on coral reefs. Glob Change Biol 10:1642-1647

Munday PL, Jones GP, Pratchett MS, Williams AJ (2008) Climate change and the future for coral reef fishes. Fish Fish 9:261-285

Nyström M, Folke C, Moberg F (2000) Coral reef disturbance and resilience in a human-dominated environment. Trends Ecol Evol 15:413-417

Pandolfi JM, Bradbury RH, Sala E, Hughes T and others (2003) Global trajectories of the long-term decline of coral reef ecosystems. Science 301:955-958

Pimm SL (1984) The complexity and stability of ecosystems. Nature 307:321-326

> Pratchett MS, Wilson SK, Baird AH (2006) Declines in the abundance of Chaetodon butterflyfishes following extensive coral depletion. J Fish Biol 69:1269-1280

Randall JE (1985) Fishes. Proc 5th Int Coral Reef Symp $1: 462-481$

Randall JE (2005) Reef and shore fishes of the South Pacific. University of Hawai'i Press, Honolulu, HI

Schmitt RJ, Holbrook SJ (2000) Habitat-limited recruitment of coral reef damselfish. Ecology 81:3479-3494

Schmitt RJ, Holbrook SJ, Osenberg CW (1999) Quantifying the effects of multiple processes on local abundance: a cohort approach for open populations. Ecol Lett 2: 294-303

Shepherd JG (1982) A versatile new stock-recruitment relationship for fisheries, and the construction of sustainable yield curves. J Cons Int Explor Mer 40:67-75

Steele MA, Forrester GE (2005) Small-scale field experiments accurately scale up to predict density dependence in reef fish populations at large scales. Proc Natl Acad Sci USA 102:13513-13516

Syms C, Jones GP (2000) Disturbance, habitat structure, and the dynamics of a coral-reef fish community. Ecology 81:2714-2729

Syms C, Jones GP (2001) Soft corals exert no direct effects on coral reef fish assemblages. Oecologia 127:560-571

> Vitousek PM, Mooney HA, Lubchenco J, Melillo JM (1997) Human-domination of Earth's ecosystems. Science 277: 494-499

Wertz S, Degrange V, Prosser JI, Poly F, Commeaux C, Guillaumaud N, LeRoux X (2007) Decline of soil microbial diversity does not influence the resistance and resilience of key soil microbial functional groups following a model disturbance. Environ Microbiol 9: 2211-2219

> Wilson SK, Graham NAJ, Pratchett MS, Jones GP, Polunin NVC (2006) Multiple disturbances and the global degradation of coral reefs: Are reef fishes at risk or resilient? Glob Change Biol 12:2220-2234

Submitted: April 24, 2008; Accepted: August 13, 2008 Proofs received from author(s): November 12, 2008 